\title{
Model Kepemimpinan yang Ideal Dalam Penataan Organisasi Gereja
}

\section{The Ideal Leadership Model in Church Organization}

\author{
Simon $^{1}$, Alvonce Poluan ${ }^{2}$ \\ ${ }^{1,2}$ Sekolah Tinggi Teologi Anugrah Indonesia \\ 1simonpetrus.45144@gmail.com,2apoluan123@gmail.com
}

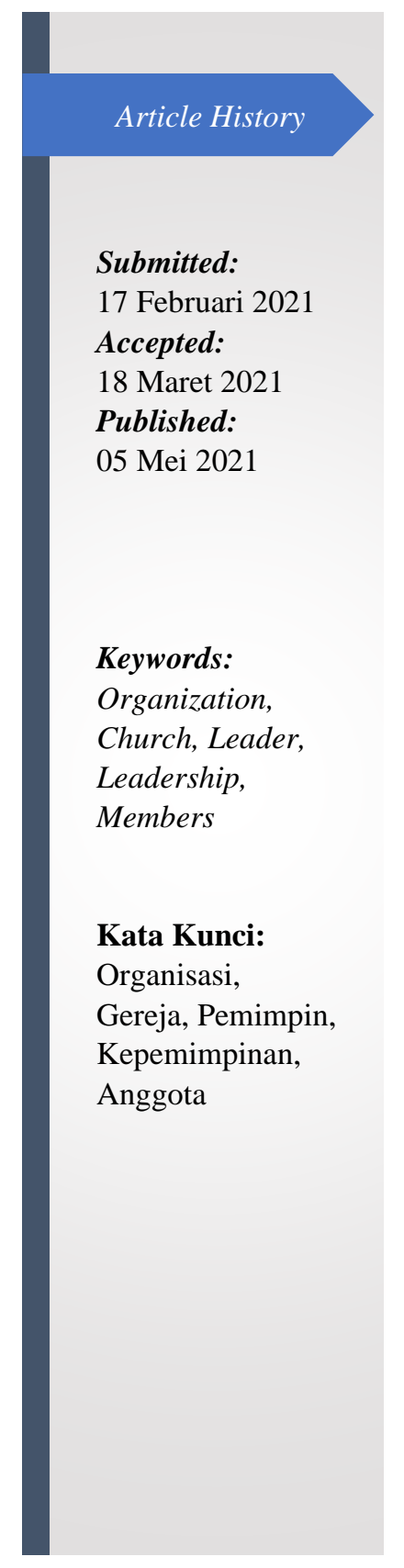

\section{Abstract}

The basic idea of this article comes from factual events there are disputes between the leaders of the church organization and the members they lead. Disputes are caused by the leadership model run by the leader in organizing the organization that does not match the expectations (expectations) of the subordinates. The research method used in the writing of this article is a qualitative method with a literature approach and in-person interviews. The description of this paper, the church organization stands on the permission of God initiated by His servants. With the organization, the church provides a sketch of who is the leader and who is being led. The leadership model needed in the organization of the church by a leader is non-tribalism, open to input and criticism, not concerned with personal interests but not to selfindulgence in practical politics. The achievement of organization missions is on the shoulders of the leader, whether to mobilize all the resources possessed by the organization components of the church.

Keywords: Abstrak
Ide dasar dari artikel ini berangkat dari peristiwa faktual, adanya perselisihan
antara pemimpin organisasi gereja dengan anggota yang dipimpin.
Perselisihan itu timbul ditenggarai oleh model kepemimpinan yang
dijalankan oleh si pemimpin dalam penataan organisasi tidak sesuai dengan
ekspektasi (harapan) oleh bawahan. Metode yang peniliti gunakan dalam
penulisan artikel ini adalah metode kualitatif dengan pendekatan kepustakaan
disertai wawancara secara langsung. Uraian dari tulisan ini, organisasi gereja
berdiri atas seijin Tuhan yang diprakarsai oleh hamba-hamba-Nya. Dengan
adanya organisasi gereja memberikan sketsa siapa yang menjadi pemimpin
dan siapa yang dipimpin. Model kepemimpinan yang dibutuhkan dalam
penataan organisasi gereja oleh seorang pemimpin adalah tidak sukuisme,
terbuka kepada masukan dan kritikan, tidak mementingkan kepentingan
pribadi maupun golongan serta tidak menceburkan diri pada politik praktis.
Tercapainya sebuah visi-misi organisasi ada dalam pundak sang pemimpin,
apakah ia bisa menggerakkan semua sumber daya yang dimiliki oleh
kompomen organisasi gereja tersebut. 


\section{Pendahuluan}

Tulisan ini saya awali dari sebuah cerita yang penulis sendiri dengar dan saksikan dari responden mengenai model kepemimpinan yang dijalankan oleh seorang pemimpin gereja dalam penataan organisasi. Responden MT menceritakan, ia menerima perlakukan dari pimpinan organisasinya secara sepihak karena merotasi (memindahkan) pelayanan penggembalaannya dengan orang lain tanpa persetujuan dari MT. ${ }^{1}$ Responden MT mengaku ia "dipaksa" oleh pimpinan organisasi untuk pindah dengan menandatangani surat perpindahan tempat pelayanan. Ada juga kasus lain berdasarkan pengakuan responden FAW, seorang pemimpin organisasi tidak transparansi menggunakan uang organisasi gereja dalam kepemimpinannya. Responden mengemukakan, uang organisasi yang seharusnya digunakan untuk kepentingan bersama, justru dipergunakan untuk kebutuhan pribadi. ${ }^{2}$ Kasus penyelewengan uang organisasi memang bukan yang baru, mengingat ini sering terjadi dalam lingkup kepemimpinan organisasi gereja. Michael mengemukakan pemilihan dalam kepemimpinan organisasi gereja, penataan manajemen gereja sering sekali menenggelamkan integritas pemimpin organisasi karena terlibat pada skandal korupsi. ${ }^{3}$

Kasus di atas hanyalah segelintir problematika adanya riak-riak dalam penataan organisasi gereja. Berbagai kasus kita dengar dan dijumpai tentang pemimpin gereja yang tidak kredibel dalam menata organisasi, sehingga menciptakan kegaduhan dan sikap antipati- bawahan terhadap pemimpin. Suherman mengemukakan pemimpin dalam sebuah organisasi mempunyai peran vital dalam mengarahkan dan mempengaruhi orang yang dipimpinnya. Bila tidak ada yang mengatur dan mengarahkan organisasi, kemungkinan kecil organisasi itu mewujudkan visi dan misinya. Oleh sebab itu, diperlukan figur seorang pemimpin untuk dapat mengelola dan mengatur organisasi untuk mencapai tujuantujuannya. ${ }^{4}$ Apabila seorang pemimpin tidak terampil dan cakap dalam menata organisasi yang di dalamnya berbagai perangkat program-program, struktur keanggotaan, tentu organisasi itu tidak akan mencapai sasaran visi-misi sebagaimana yang dikehendaki. Watt mengemukakan para pemimpin gereja saat ini perlu mempersiapkan orang lain untuk kepemimpinan organisasi yang efektif dengan cara mendidik, melengkapi, serta memberdayakan anggota yang mampu mempengaruhi orang lain bila ingin mencapai visimisi organisasi. Ini semua dapat dicapai bila pemimpin organisasi menunjukkan kepemimpinan etis dengan cara bertanggung jawab, serta bersikap menghamba. ${ }^{5}$

\footnotetext{
${ }^{1}$ Wawancara penulis dengan responden MT mengenai kesedihannya karena pimpinan organisasi gereja merotasi tempat penggembalaanya di tempat yang baru, namun tempat yang baru itu tidak ada jemaat. Responden MT dipindahkan dari gereja yang sudah permanen dan ada jemaat, ketempat baru yang tidak ada jemaat bahkan rumah ibadah status kontrakan. (Wawancara peneliti dengan responden MT 2019).

2 Wawancara penulis dengan responden FAW tentang pro kontra kurangnya transfaransi dalam pengalokasian uang organisasi gereja. (Wawancara penulis dengan FAW 2019).

${ }^{3}$ Michael Kpughe Lang, "The Patterns of Corruption in Christian Churches of Cameroon: The Case of the Presbyterian Church in Cameroon," Transformation 31, no. 2 (2014): 132-144.

${ }^{4}$ Usep Deden Suherman, "Pentingnya Kepemimpinan Dalam OrganisasI," Jurnal Ilmu Akuntansi Dan Bisnis Syariah 1, no. 2 (2019).

${ }^{5}$ Willis M Watt, "Relational Principles for Effective Church Leadership," Journal of Leadership Education 13, no. 2 (2014): 125-126.
} 
Bila model kepemimpinan ranah sekuler prioritas kapabilitas diri dan jenjang akademik untuk memimpin dalam penataan perusahaan atau lembaga, akan tetapi tidak demikian utamanya dalam kepemimpinan organisasi gereja. Mengapa, karena organisasi gereja bergerak bukan untuk mencari profit, namun organisasi gereja hadir sebagai wadah untuk mengemban tugas amanat Agung yang dijalankan oleh setiap para hambanya. Reslawaty menyatakan organisasi gereja yang dibentuk oleh hamba-hamba Tuhan didesain agar bekerja sama dalam rangka mencapai tujuan bersama. Dengan berdirinya organisasi gereja agar umat Allah yang disebut rakyat menurut pemerintah untuk memenuhi kebutuhan rohani. Begitu juga dengan organisasi atau lembaga pemerintah terbentuk karena adanya rakyat yang disebut umat Allah menurut gereja untuk memenuhi kebutuhan jasmani. ${ }^{6}$

Fakta faktual adanya pemimpin gereja dalam penataan organisasi melalui kepemimpinannya tidak seperti yang dikehendaki oleh anggotanya serta tidak membawa organisasi itu kearah yang dapat menampung semua aspirasi bawahannya. Bahkan jabatan sebagai pemimpin dipergunakan untuk kepentingan pribadinya, bukan lagi kepentingan secara korporat. Model kepemimpinan yang seperti itu tentu tidak mencerminkan nilai-nilai kepemimpinan yang berdasarkan firman Allah. Sejatinya dasar dari kepemimpinan Kristen berdasarkan firman Allah (Alkitab) di dalam pribadi Yesus Kristus. Semestinya model kepemimpinan di dalam penataan organisasi gereja memiliki keunikan khusus namun tetap berkiblat kepada apa yang Yesus Kristus terapkan. ${ }^{7}$ Kepemimpinan sejati tidak terpaku pada ideologi atau visi individu. Model kepemimpinan seperti ini hanya akan efektif diwaktu tertentu saja, namun tidak akan berdampak signifikan diruang lingkup yang lebih besar. ${ }^{8}$

Pertanyaan penelitian yang akan dikemukakan dalam artikel ini adalah apa saja yang harus dimiliki oleh seorang pemimpin gereja dalam penataan organisasi? Tulisan ini menguraikan bagaimana seharusnya model kepemimpinan yang dibutuhkan oleh seorang pemimpin untuk menata organisasi gereja. Di tengah banyaknya organisasi gereja yang terdaftar secara resmi di Lembaga Bimas Kristen, diharapkan uraian dari tulisan ini memiliki kontribusi secara teoritis dan praksisnya. Wujud dari kontribusi teoritisnya, tulisan ini menjadi panduan bagi mereka yang sedang menjabat sebagai pemimpin organisasi. Sementara praksisinya, dengan membahas topik ini teraplikasikan bagi setiap hamba Tuhan yang memimpin walau dalam scope gereja lokal atau akan menjadi pemimpin organisasi dikemudian hari.

\section{Metode Penelitian}

Mulyana mengemukakan metode penelitian adalah proses, prinsip dan prosedur yang digunakan untuk suatu pendekatan dalam mengkaji topik penelitian hingga mencari jawaban terhadap topik yang diperdebatkan. ${ }^{9}$ Metode yang penulis gunakan dalam penelitian ini

${ }^{6}$ Reslawaty, "Pandangan Pimpinan Gereja Tentang Pengaturan Organisasi Gereja Di Provinsi Jawa Barat," Jurnal Multikultural \& Multireligius 13, no. 3 (2014): 74.

${ }^{7}$ Raymondus Indra Widjaja, "Implementasi Karakter Pemimpin Kristen,” Agora 3, no. 1 (2015): 672676.

${ }^{8}$ Wessel Bentley, "The Formation of Christian Leaders: A Wesleyan Approach," Koers 75, no. 3 (2010): 560.

${ }^{9}$ Dedy Mulyana, Metode Penelitian (Bandung: Rosdakarya, 2002), 120. 
adalah metode kualitatif dengan pendekatan studi kepustakaan disertai wawancara langsung. Pengertian studi kepustakaan yang dimaksud berdasarkan uraian Zed adalah pendekatan kepustakaan untuk menjawab pertanyaan penelitian, sebab penelitian tersebut hanya dapat dijawab melalui penelitian kepustakaan karena data penelitian yang diperoleh berasal dari sumber perpustakaan. Selain dengan pendekatan kepustakaan, wawancara secara langsung digunakan untuk mendukung keabsahan data pada setiap poin mengenai model kepemimpinan yang dibutuhkan dalam penataan orgnaisasi gereja. Tentunya model wawancara yang penulis gunakan dengan bertatap muka secara langsung atau wawancara tidak langsung dengan menggunakan sarana media seperti WhatsApp dan Telephone. Menurut Emzir wawancara sebagai interaksi bahasa yang berlangsung antara dua orang dalam situasi saling berhadapan salah seorang, yaitu yang melakukan wawancara meminta informasi atau ungkapan kepada orang yang diteliti yang berputar disekitar pendapat dan keyakinannya. ${ }^{10}$

\section{Hasil dan Pembahasan \\ Organisasi Gereja Dalam Perspektif Alkitab}

Kamus Besar Bahasa Indonesia mendefinisikan organisasi sebagai struktur kesatuan yang terdiri atas bagian-bagian atau tingkat jabatan dalam perkumpulan untuk mencapai tujuan yang diagendakan organisasi itu. ${ }^{11}$ Sementara Hasibuan mengemukakan organisasi adalah suatu sistem perserikatan formal, berstruktur, dan terkoordinasi dari sekelompok orang yang bekerja sama dalam mencapai tujuan tertentu. ${ }^{12}$ Berdirinya sebuah organisasi tentunya hasil dari inisiatif berpikir sekelompok orang agar struktur dalam jabatan yang disandang dapat dilihat serta tersusun secara sistematis. Organisasi juga berdiri untuk mengkoordinir kepentingan bersama agar tidak ada yang terlewatkan oleh anggota yang tergabung. Melalui kehadiran organisasi semakin dirasakan urgensinya bagi setiap management di tingkat manapun dengan tujuan praktis untuk mendeterminasi bagaimanakah perilaku manusia itu mempengaruhi usaha-usaha pencapaian tujuan organisasi. ${ }^{13}$

Organisasi gereja juga lahir dan berdiri merupakan inisiatif dari hamba-hamba Tuhan yang bertujuan mengatur dan menata pelayanan melalui struktural jabatan-jabatan yang disandang oleh anggota dalam pelayanan gerejawi. Saat ini jumlah organisasi gereja yang terdaftar secara resminya menurut Asnawati dalam skala nasional sudah lebih dari 323 denominasi atau organisasi gereja di Indonesia, sedangkan untuk skala wilayah Papua sudah ada sekitar 39 denominasi gereja yang terdaftar secara resminya. ${ }^{14}$ Banyaknya organisasi gereja saat ini, masing-masing tentu mempunyai visi-misi, aturan, tujuan bagaimana dalam

\footnotetext{
${ }^{10}$ Emzir, Metode Penelitian Kualitatif Analisis Data (Jakarta: PT Raja Frafindo Persada, 2016).

11 Team Balai Pustaka, Kamus Besar Bahasa Indonesia, 3rd ed. (Jakarta: Balai Pustaka Departemen Pendidikan Nasional, 2003), 803.

12 Hasibuan. M, Organisasi Dan Motivasi Dasar Peningkatan Produktivitas (Jakarta: Bumi Aksara, 2003).

13 Dody Hermana \& Ujang Cepi Barlian, "Komunikasi Dalam Organisasi," Jurnal Administrasi Pendidikan 2, no. 2 (2004).

${ }^{14}$ Asnawati, "Pandangan Pemimpin Gereja Tentang Pengaturan Organisasi Gereja Di Provinsi Papua," Jurnal Multikultural \& Multireligius 14, no. 3 (2015): 61.
} 
melebarkan eksistensi organisasi gereja mereka untuk mencapai sasaran yang dikehendaki oleh para pemimpin tersebut.

Dengan semakin bertambahnya organisasi gereja secara kuantitas dapat dilihat dari dua sisi. Dari sisi positif, organisasi gereja berdampak kepada pertambahan kuantitas jumlah orang percaya, bertambahnya lembaga-lembaga misi penginjilan, dan institusi-institusi yang bercorak kekristenan. Dari sisi negatifnya, makin banyaknya organisasi gereja bertambah tentu akan membuat satu dengan yang lain bersaing organisasi siapa yang lebih besar, jemaat siapa paling banyak terdaftar pada organisasi tersebut. Ini pula yang disoroti oleh Direktorat Jenderal Bimas Kristen bahwa organisasi atau denominasi gereja baru yang muncul, seringkali bukan karena perbedaan teologis, tetapi karena semangat paham missionary church planting dan duniawi semata. Padahal dengan terbentuknya organisasi atau denominasi baru tersebut akan diikuti pendirian gedung gereja baru yang prosesnya tidak mudah. ${ }^{15}$

Dengan merujuk makna kata organisasi mengenai kesatuan yang terdiri atas bagianbagian atau tingkat jabatan, organisasi memiliki landasan teologis yang diyakini berasal ketika Yitro mertua Musa menyarankan agar ia memilih tua-tua Israel yang berkriteria takut akan Tuhan, cakap mengajar serta benci kepada suap. Atas saran dari Yitro, Musa memilih sebagian dari orang-orang Israel untuk menjadi pemimpin sepuluh orang sampai seribu orang untuk menjadi hakim bagi umat Israel. Tujuan Musa menetapkan hal ini agar orangorang yang dipilihnya dapat menjadi hakim bagi umat Israel ketika mereka melakukan pelanggaran (Kel. 18:13-27). Anthoni mengemukakan pilihan Tuhan kepada Musa agar Ia menjalankan atau mengorganisir rencana kepulangan umat Allah. Itulah sebabnya kitab Keluaran banyak mencatat prinsip-prinsip kepemimpinan dan delegasi dalam organisasi yang dipratekkan sampai hari ini baik dalam sekuler maupun di gereja. Keluaran 18:13-24 adalah contoh utama prinsip-prinsip delegasi yang bertujuan mengurangi beban kerja dan tanggung jawab Musa. ${ }^{16}$

Perjanjian Baru semakin memperjelas mengenai fungsi dan struktural dari sebuah organisasi. Ketika momen pencurahan Roh Kudus dimulai di loteng Yerusalem, inilah cikalbakal lahirnya gereja. Setelah gereja lahir, maka mulailah terbentuk stuktural dalam kepemerintahan di gereja. Thiessen menyatakan pada mulanya tidak ada lembaga atau organisasi gereja, yang ada hanya sebatas ikatan kasih, persekutuan, ajaran, dan kerja sama dalam bentuk kelompok. Hadirnya organisasi gereja disebabkan makin longgarnya kepemimpinan para rasul karena tingkat kesibukan mereka dalam melayani, karena itu perlahan digantikan organisasi yang lebih ketat. Mereka yang menggantikan kepemimpinan para rasul melalui struktural organisasi adalah para anggota gerejawi yang sejati mereka terdorong untuk mengorganisasi jemaat-jemaat lokal agar perubahan-perubahan batin terjadi akibat iman kepada Kristus diwujudkan untuk kepentingan bersama dan menyelamatkan yang belum percaya. ${ }^{17}$

\footnotetext{
15 Asnawati, "Pandangan Pemimpin Gereja Tentang Pengaturan Organisasi Gereja Di Provinsi Papua."

16 Michael J. Anthony, Foundaion Of Mnistry An Introduction Christian Education For A New Generation, ed. Christian A Tomatala (Malang: Gandum Mas, 2012). 2010).

${ }^{17}$ Henry C Thiessen, Teologi Sistimatika, ed. Vernon D Doerksen, 8th ed. (Malang: Gandum Mas,
} 
Potret kehadiran organisasi gereja dapat ditelusuri melalui kitab Kisah Para Rasul dengan adanya penataan kehidupan jemaat secara bersama serta mengakomodinir kepentingan jemaat yang terabaikan. Kisah Para Rasul 6:1-8 mencatat administrasi yang terjadi sebagai respon terhadap kebutuhan para janda-janda yang terabaikan karena tidak menerima jatah makanan harian. Peristiwa ini disebabkan karena para rasul bekerja terlalu sibuk seiring makin bertambahnya tanggung jawab mereka. Atas dasar itulah muncul respons penerapan struktur- organisasi baru untuk memastikan distribusi manakan dengan baik. Prinsip-prinsip di dalam kitab Kisah Para Rasul ini banyak ditiru dan dicontoh baik oleh organisasi sekuler maupun organisasi berbasis agama. Hal ini memperlihatkan bahwa Tuhan adalah Allah yang teratur, organisasi dan administrasi adalah konsep alkitabiah yang berasal dari Tuhan sendiri. ${ }^{18}$ Hadirnya organisasi gereja merupakan bagian dari inisiatif Allah untuk menata kehidupan moral, iman orang percaya agar tertib dan teratur, serta melalui organisasi Allah ingin menggunakannya untuk penyebaran Injil melalui lembaga yang resmi pemerintahan. Borrong mengemukakan poin penting dalam penataan organisasi itu bukan kepemimpinannya, tetapi berkenaan dengan penataan pelayanan gereja kepada Tuhan dan bagi dunia. Kepemimpinan gereja tidak bertujuan membuat organisasi gereja dengan baik, tetapi menata organisasi gereja dengan baik supaya pelayanan dan kesaksian kepada dunia berjalan dengan baik. ${ }^{19}$

\section{Kepemimpinan yang Ideal dalam Penataan Organisasi}

Tidak Sukuisme

Model kepemimpinan Kristen yang ideal yang dapat dijadikan sebagai barometer adalah Yesus sendiri. Yesus adalah contoh yang kongkrit bagaimana menjadi seorang pemimpin yang diteladani serta menjadi teladan dalam menata orang yang dipimpin. Itulah sebabnya kepemimpinan Kristen erat kaitannya dengan kepemimpinan melayani yang berasal dari teladan Yesus Kristus. Pemimpin Kristen harus memiliki gaya dan pendefinisian yang benar bahwa menjadi pemimpin berarti siap melayani dan memberi teladan dalam organisasi gereja yang dipimpinnya. ${ }^{20}$ Clarke mengemukakan dalam sejumlah suratnya, Paulus mendesak pembacanya untuk mencontoh bagaimana menerapkan model kepemimpinan kristiani dengan mencontoh dirinya, namun utamanya ia menekankan agar berpusat kepada Kristus sebagai yang utama. ${ }^{21}$ Menjalankan model kepemimpinan dalam penataan organisasi gereja bukan sekadar soal teknis organisasional yang dapat dijalankan semata-mata dengan kiat-kiat manajemen. Akan tetapi, kepemimpinan dalam penataan organisasi gereja mengandung aspek spiritual yang membedakannya dari sekadar teknik manajemen. ${ }^{22}$

18 Michael J. Anthony, Foundaion Of Mnistry An Introduction Christian Education For A New Generation.

19 Robert P Borrong, “Kepemimpinan Dalam Gereja Sebagai Pelayanan," Voice of Wesley: Jurnal Ilmiah Musik dan Agama 2, no. 2 (2019).

${ }^{20}$ Suhadi Suhadi and Yonatan Alex Arifianto, "Pemimpin Kristen Sebagai Agen Perubahan Di Era Milenial," EDULEAD: Journal of Christian Education and Leadership 1, no. 2 (2020): 129-147.

${ }^{21}$ Andrew David Clarke, ““ Be Imitators of Me': Paul's Model of Leadership,” Tyndale Bulletin (1998).

${ }^{22}$ Yahya Wijaya, "Kepemimpinan Yesus Sebagai Acuan Bagi Kepemimpinan Gereja Masa Kini," Jurnal Jaffray 16, no. 2 (2018): 129-144. 
Kepemimpinan yang ideal dalam penataan organisasi adalah tidak sukuisme. Sukusime dapat diartikan sebagai paham atau praktik yang mementingkan sukunya atau klan (marga) sendiri. Menurut Kun Maryati makna lain dari sukuisme ikatan-ikatan seseorang dalam kehidupan sosial yang sangat berpegang teguh terhadap hal-hal yang dibawa sejak lahir baik berupa suku, bangsa, kepercayaan, ras, adat-istiadat dan daerah kelahiran. ${ }^{23}$ Oleh sebab itu kualitas dari pemimpin pada umumnya dianggap sebagai faktor terpenting, karena berhasil dan gagalnya suatu organisasi baik yang berorientasi bisnis maupun organisasi yang bergerak dalam keagamaan, terletak pada model kepemimpinan yang dijalankan. ${ }^{24}$ Tercapainya keberhasilan dalam menata organisasi gereja, pemimimpin tidak sukusime. Bila seorang pemimpin organisasi gereja memiliki unsur kesukuan, ia akan pilih-pilah dalam menempatkan jabatan struktural yang strategis kepada orang-orang yang sepemahaman dengan dia, kesamaan secara suku, budaya dan klan (marga).

Penataan organisasi gereja tidak akan berjalan maksimal apalagi mencapai visi-misi bila kepemimpinan yang dijalankan oleh seorang pemimpin menganut sukusime. Mengapa, karena organisasi itu hanya akan bergerak atau diisi oleh orang-orang yang sepemahaman dengan yang memimpin. Organisasi gereja akan sulit berkembang dan maju, karena tidak diisi oleh orang-orang yang berkompeten dibidangnya, karena mereka tidak terorganisir hanya karena model kepemimpinan seseorang yang masih berpatokan pada kesamaan paham, suku, budaya dan klan. Pemimpin yang memimpin dengan mengedepankan seperti ini adalah pemimpin yang sukuisme. Welton menyatakan kepemimpin yang sukses itu membangun budaya perubahan di kelembagaan organisasi dan berkolaborasi dengan semua orang tanpa melihat latar belakang. Ini dapat dilakukan bila pemimpin menginvestasikan waktunya secara efektif dan menciptakan kepercayaan kepada orang lain dengan memberdayakan anggota dan mengesampingkan sikap rasisme (kesukuan). ${ }^{25}$

Ada sebuah organisasi gereja yang sudah lama berdiri namun pemimpin utama organisasi gereja itu hanya dari suku tertentu. Karena organisasi gereja itu hanya dari suku tertentu yang menjadi pemimpin sinode, orang lain pun melabeli bahwa organisasi gereja itu hanya diperuntukkan kepada suku itu. ${ }^{26}$ Santoso mengemukakan model kepemimpinan di wilayah Asia bertumbuh subur dengan kesamaan yang sama, agama, dan nilai-nilai sosial yang oleh masyarakat lokal. Oleh karena itu, kita masih cenderung melihat dan menjumpai model kepemimpinan dimasyarakat Asia terkait dengan budaya lokal masyarakat. ${ }^{27}$ Terciptanya penataan organisasi gereja yang mengarah pada kemajuan dapat dicapai bila seorang pemimpin tidak menjalankan model kepemimpinan sukuisme. Ini akan berdampak

${ }^{23}$ Kun Maryati, Sosiologi (Solo: PT. Tiga Serangkai Pustaka Mandiri, 2014).

${ }^{24}$ Susilo Toto Raharjo and Durrotun Nafisah, "Analisis Pengaruh Gaya Kepemimpinan Terhadap Kepuasan Kerja, Komitmen Organisasi Dan Kinerja Karyawan (Studi Empiris Pada Departemen Agama Kabupaten Kendal Dan Departemen Agama Kota Semarang)," Jurnal Studi Manajemen Organisasi 3, no. 2 (2006): 69-81.

25 Anjalé D Welton, Devean R Owens, and Eboni M Zamani-Gallaher, “Anti-Racist Change: A Conceptual Framework for Educational Institutions to Take Systemic Action," Teachers College Record 120, no. 14 (2018): 10-11.

${ }^{26}$ Wawancara penulis dengan JS tentang kepemimpinan gereja.

${ }^{27}$ C Budi Santoso, "Exploration Of Asia Leadership Theory: Looking For An Asian Role In The Field Of Leadership Theory," Journal of Leadership in Organizations 1, no. 1 (2019). 
dapat merealisasikan visi-misi organisasi, mengkoordinir kepentingan semua pihak bila sipemimpin menjalankan model kepemimpinnya tidak sukuisme. Tidak adanya unsur yang mengarah pada sikap sukuisme, tentu akan mengedepankan gol yang ingin dicapai oleh organisasi. Sikap tidak sukuisme juga akan memperkaya berbagai pandangan dari para anggota sehingga menciptakan sumbangsih inspirasi baru dalam kemajuan organisasi gereja. Tidak sukuisme dalam menata organisasi gereja juga menghilangkan praktek-praktek yang mengarah nepotisme dan keberpihakan kepada orang yang sama secara suku, budaya dan klan.

\section{Terbuka Terhadap Masukan dan Kritikan}

Memimpin organisasi gereja tidak sama dengan memimpin gereja lokal. Jika dalam kepemimpinan gereja lokal gembala menjadi sentral dalam memutuskan dan merealisasikan program-program gereja setempat, tidak demikian halnya dalam kepemimpinan ditingkat organisasi. Mereka yang menjabat sebagai pemimpin organisasi gereja perlu memahami, bahwa setiap program kerja yang berkaitan dengan organisasi, tidak etis bila mengambil keputusan hanya berdasarkan pertimbangan pribadi. Seorang pemimpin harus bijaksana dengan tetap melibatkan bawahan yang dipimpinnya atas apa yang akan direalisasikan di dalam pelaksaan kerangka kerja organisasi gereja. Seorang pemimpin berkewajiban untuk mengenal secara keseluruhan anggota organisasi yang dipimpinnya agar dapat menumbuhkan kerja sama yang harmonis di antara sesama anggota. Di sini sini peran pemimpin menjadi sangat urgent guna terciptanya keberhasilan organisasi yang dipimpinnya dalam hal arahan (direktif), supportif, partisipatif bagi kinerja bawahannya.

Model kepemimpinan dalam penataan organisasi gereja oleh seorang pemimpin adalah ia terbuka terhadap masukan dan kritikan. Yang dimaksud dengan terbuka terhadap masukan dan kritikan adalah mampu mempertimbangkan dan bersedia mengganti program yang ditetapkan oleh pemimpin, dengan mengganti ide-ide dari bawahan karena aspirasi yang ditampung lebih baik dari yang sudah ditetapkan pemimpin tersebut. Terbuka terhadap masukan dan kritikan juga dapat diartikan pemimpin berbesar hati ketika bawahannya mengkritik karena kebijakan yang diperbuat tidak tepat sasaran serta tidak mengakomodir kepentingan secara bersama. Terbuka terhadap masukan dan kritikan juga dapat dimaknai tidak menggunakan power atau kekuasaannya untuk mengintimidasi bawahan hanya karena pemimpin itu menerima kritikan. Terciptanya keberhasilan seorang pemimpin bergantung dari kemampuan dia apakah mampu membangun orang disekitarnya, karena keberhasilan sebuah organisasi sangat tergantung pada potensi sumber daya manusia dalam organisasi tersebut. Jika sebuah organisasi atau masyarakat mempunyai banyak anggota dengan kualitas pemimpin, organisasi tersebut akan berkembang dan menjadi kuat. ${ }^{28}$

Pemimpin organisasi gereja yang terbuka terhadap masukan dan kritikan dari bawahannya juga menunjukkan ia terampil dalam pengelolaan emosionalnya. Karena seorang pemimpin yang memberikan perhatian pribadi kepada bawahan, memperlakukan

${ }^{28}$ Supardi Asep Solikin, H.M Fatchurahman, "Pemimpin Yang Melayani Dalam Membangun Bangsa Yang Mandiri," Anterior Jurnal 16, no. 2 (2016): 99. 
setiap bawahan sebagai partner, dan bersinergi merupakan komponen kepemimpinan transformasional. Kepemimpinan transformasional erat kaitannya pada sikap peduli dan empati sehingga orang yang dipimpin akan memberikan reaksi yang positif. Jika pemimpin menginginkan ada respons yang baik dan motivasi untuk bekerja menjadi lebih baik adalah dengan menumbuhkan sikap keterbukaan pada masukan dan kritikan. ${ }^{29}$ Mengapa di dalam penataan organisasi gereja pemimpin didorong untuk terbuka kepada masukan dan kritikan, agar ia tidak terjebak pada pola kepemimpinan yang otoriter. Kepemimpinan yang otoriter selalu memusatkan keputusan dan kebijakan yang dia perbuat dan berfokus penuh kepada keinginan dirinya. Segala pembagian tugas dan tanggung jawab dipegang oleh si pemimpin yang otoriter, sedangkan para bawahan hanya melaksanakan tugas yang telah diberikan. ${ }^{30}$

Kerap kali perdebatan dan pertentangan terjadi dalam kepemimpinan organisasi gereja hanya karena pemimpin tersebut sulit menerima masukan dan kritikan dari para bawahan (pendeta). Tak jarang bila pemimpin organisasi gereja diberi masukan dan kritikan, ia terkadang menggunakan landasan biblis sebagai mekanisme pertahanan diri bahwa seorang pemimpin itu adalah biji mata Tuhan yang dipilih untuk memimpin. Pemimpin yang menggunakan dalil biblis ketika diberi kritikan, motifnya bermuara membungkam bawahan agar tidak vokal dalam memberi masukan atau kritikan. Model Pemimpin yang bersikap seperti ini merupakan tidak etis serta jauh dari prinsip-prinsip dari kepemimpinan kristiani yang berkiblat kepada Yesus. Sitepu mengemukakan pemimpin gereja masa kini belum termasuk pemimpin yang baik (good leader), kepemimpinan yang benar dan berkualitas bisa menjadi teladan bagi para generasi penerus. Potret kepemimpinan dalam gereja di masa kini ada yang tidak ideal karena tidak sesuai dengan kepemimpinan yang alkitabiah, oleh karena perubahan situasi, persaingan organisasi secara eksternal dan juga persaingan gereja secara internal. ${ }^{31}$ Ini pula yang dikemukakan oleh responden hamba Tuhan FAJ, pemimpinnya sulit menerima masukan dan kritikan dari anggotanya. Pemimpin yang tidak terbuka terhadap masukan dan kritikan dari anggota akan menciptakan hubungan yang tidak bersahabat.

Model kepemimpinan yang dibutuhkan dalam penataan organisasi gereja terbuka pada masukan dan kritikan. Hal ini penting diterapkan agar menciptakan keharmonisan hubungan dengan bawahan, serta menumbuhkan keberagaman ide yang dapat berdampak pada lahirnya gagasan-gagasan baru dalam pengembangan organisasi. Terciptanya hubungan yang menyenangkan dalam organisasi harus diprakarsai semua pihak yang dinahkodai sendiri oleh pemimpin organisasi. Iklim yang menyenangkan akan terbentuk walau tidak bisa dipaksakan kepada setiap orang, akan tetapi harus difasilitasi oleh budaya berorganisasi. ${ }^{32}$ Oleh sebab itu para pemimpin harus menyadari bahwa mereka bukan penguasa tunggal dalam organisasi, tetapi harus berprinsip sebagai pelayan-pelayan yang

${ }^{29}$ Suryana, "Pentingnya Kecerdasan Emosi Bagi Kepemimpinan Yang Efektif Di Era Milenial Revolusi 4.0.," Jurnal Inspirasi 10, no. 1 (2019): 84-86.

${ }^{30}$ Herlinda Maya Kumala Sari, "Pengaruh Budaya Organisasi Dan Gaya Kepemimpinan Otoriter Terhadap Loyalitas Melalui Kepuasan Kerja Dan Stres Kerja Karyawan Institusi X Di Kediri,” JBMP (Jurnal Bisnis, Manajemen dan Perbankan) 2, no. 1 (2016): 15-30.

${ }^{31}$ Elisabeth Sitepu, “Kepemimpinan Kristen Di Dalam Gereja,” Jurnal Pendidikan Religius 1, no. 1 (2019): 7-11.

${ }^{32}$ Asep Suryana, “Membangun Kepemimpinan Yang Menyenangkan,” Pedagogia 12, no. 1 (2014): 34. 
berperan sebagai motivator, fasilitator, moderator, dan koordinator dalam pengelolaan organisasi gereja. Itu berarti tidak ada struktur kepemimpinan yang bersifat hierarkhis melainkan representatif. ${ }^{33}$ Karena itu kepemimpin Kristen harus mewujudkan karakteristik sebagai agen perubahan, kreatif dalam tindakan, menunjukkan rasa terima kasih kepada anggota tim, memperhatikan kebutuhan orang lain, berpikir dari perspektif global, dan mengatakan kebenaran walau dalam situasi sulit. ${ }^{34}$ Dengan membawa perubahan itu menjunjukkan pribadi yang bertanggung jawab untuk merekonstruksi system dan tingkah laku anggota yang dipimpin di dalam organisasi. ${ }^{35}$

\section{Tidak Mementingkan Kepentingan Pribadi Dan Golongan}

Ketika seseorang menjabat sebagai pemimpin utama dalam struktur organisasi gereja, point utama dalam kepemimpinannya dengan menjalankan kepentingan organisasi. Bila seorang pemimpin gereja memimpin organisasi, tetapi kepemimpinan yang dijalankan bermuara pada kepentingan pribadi maupun kelompoknya merupakan bentuk penyelewengan. Pemimpin harus mampu menjadi penggerak, pendorong, pelindung sekaligus pelayan untuk bertanggung jawab berbagai aktivitas organisasi. Pemimpin juga harus mampu mengenali secara tepat dan utuh tentang dirinya terlebih apa saja yang menjadi aspirasi angota yang dipimpin. ${ }^{36}$ Bila pemimpin organisasi gereja menjalankan kepemimpinannya dengan bermuara kepada kepentingan pribadi dan golongan, ia tidak menjadi pemimpin bagi semua orang yang tergabung dalam organisasi tersebut. Ia juga tidak menata organisasi gereja itu sebagaimana yang diharapkan oleh khalayak orang banyak. Usman mengemukakan seorang pemimpin secara positif menerapkan komitmen ini dalam tiga cara, yaitu membangun organisasi, mendukung manajemen organisasi yang lebih tinggi, dan menjalankan nilai-nilai dasar organisasi yang telah disepakati secara bersama-sama. ${ }^{37}$

Banyak pemimpin gereja yang sibuk dengan aktivitas terutama dalam memperoleh kekuasaan dan kurang memperhatikan orang-orang yang dipimpinnya. Akibatnya banyak orang Kristen yang kecewa dengan kondisi kepemimpinan seperti itu. ${ }^{38}$ Penataan organisasi gereja yang ideal dimulai dari pemimpin organisasi gereja mengenyampingkan kepentingan pribadi maupun golongannya. Dengan mengesampingkan kepentingan pribadi dalam penataan organisasi menunjukkan seorang pemimpin itu melayani kepentingan semua pihak. Karena pemimpin yang melayani adalah pemimpin yang mau mendengar setiap kebutuhan, impian, dan harapan dari mereka yang dipimpin. Pemimpin yang melayani adalah pemimpin yang dapat mengendalikan ego dan kepentingan pribadinya melebihi kepentingan bersama

\footnotetext{
${ }^{33}$ Borrong, "Kepemimpinan Dalam Gereja Sebagai Pelayanan."

34 Tim Gregory, "Christian Leaders as Agents of Change: A Biblical Perspective with Practical Implications," in Modern Metaphors of Christian Leadership (Springer, 2020), 21-40.

${ }^{35}$ Suhadi and Arifianto, "Pemimpin Kristen Sebagai Agen Perubahan Di Era Milenial."

${ }^{36}$ Fajar Apriani, "Menciptakan Pemimpin Yang Melayani," JAKPP (Jurnal Analisis Kebijakan \& Pelayanan Publik) 1, no. 1 (2015): 110.

37 Husaini Usman, "Kepemimpinan Berkarakter Sebagai Model Pendidikan Karakter," Jurnal Pendidikan Karakter 3, no. 3 (2013): 269.

${ }^{38}$ Harun Y Natonis, "Pemimpin Yang Menghamba, Bukan Diperhamba," Voice of Wesley: Jurnal Ilmiah Musik Dan Agama 2, no. 1 (2018).
} 
atau mereka yang dipimpinnya. ${ }^{39}$ Mengapa seorang pemimpin organisasi gereja perlu mengesampingkan kepentingan pribadi dalam penataan organisasi? Karena seorang pemimpin mempunyai posisi yang dominan dalam menentukan sukses tidaknya suatu organisasi. Kinerja yang dihasilkan oleh suatu organisasi merupakan gambaran kinerja yang diberikan oleh pemimpin dalam mengelola organisasi tersebut. Itu sebabnya pemimpin yang baik akan dapat mengarahkan, mempengaruhi, dan mengawasi orang lain untuk melaksanakan tugas sesuai dengan perintahnya, sehingga diharapkan dapat mewujudkan tercapainya tujuan organisasi. ${ }^{40}$ Tidak mungkin seorang pemimpin organisasi gereja dapat mengarahkan dan memengaruhi anggota, bila setiap kebijakan dan keputusan yang dijalankan tidak kepentingan secara bersama-sama.

Bila model kepemimpinan yang dijalankan oleh seorang pemimpin dalam penataan organisasi tidak mengarah pada kepentingan pribadi dan golongan, maka organisasi gereja akan tertata secara teratur, terstruktur dan sistematis. Dampak dari hal tersebut, program organisasi gereja akan berjalan dengan baik, kebutuhan setiap anggotanya akan terorganisir, terlebih akan menciptakan hubungan harmonis antara anggota dan pimpinan. Tanyid mengungkapkan pemimpin yang benar itu bila ia mendidik bawahannya dengan benar dan memperlakukan orang yang dipimpin itu berdasarkan kebenaran firman Tuhan. Bila hal ini dilakukan oleh seorang pemimpin ia menjalankan fungsi sekaligus sebagai pemimpin yang mendidik. Walau dalam memimpin akan menemui tantangan, cobaan, tekanan dan penolakan, namun jika dalam setiap prilaku dan tindakan seorang pemimpin sebagai pendidik selalu berkomitmen melakukan kebenaran dan memperlakukan orang yang dipimpinnya berdasarkan kebenaran, maka sesungguhnya model kepemimpinan itulah yang kuat. $^{41}$

\section{Tidak Terlibat Pada Politik Praktis}

Pada tahun 2019 ketika pemilihan presiden dan wakil presiden dilaksanakan, ada sebagian pemimpin organisasi gereja terlibat politik praktis. Mereka secara terang-terangan menunjukkan dukungan politiknya kepada salah salah satu calon wakil presiden. Contohnya pendeta EG yang berdoa agar Tuhan memenangkan capres yang didukungnya. Ada juga pendeta RS yang mengemukakan secara gamblang selama Tuhan menyertai Komisi Pemilihan Umum, maka kemenangan menjadi milik capres yang didukungnya. ${ }^{42}$ Ada jug pendeta JN, YP secara terbuka memperlihatkan afiliasi politiknya kepada capres tersebut. Dengan menunjukkan afiliasi politik dan mengkampanyekan capres tertentu agar dipilih oleh jemaat, itu menunjukkan para pendeta itu terjerumus pada politik praktis. Fenomena sebagian pendeta terjerumus dalam pusaran politik praktis memunculkan tanggapan dari Lembaga Persatuan Gereja Indonesia. Lembaga PGI sendiri menghimbau agar denominasi

\footnotetext{
39 Asep Solikin, H.M Fatchurahman, "Pemimpin Yang Melayani Dalam Membangun Bangsa Yang Mandiri," 100

40 Anung Pramudyo, "Implementasi Manajemen Kepemimpinan Dalam Pencapaian Tujuan Organisasi," Jurnal bisnis, manajemen, dan akuntansi 1, no. 2 (2013).

${ }^{41}$ Maidiantius Tanyid, "Kualitas Pemimpin Sebagai Pendidik Dalam Menghadapi Konflik," BIA': Jurnal Teologi dan Pendidikan Kristen Kontekstual 1, no. 1 (2018): 124-137.

42 "Tuhan Pun Diminta Untuk Memenangkan Prabowo.... - Kompasiana.Com."
} 
gereja bersama para pemimpinnya tidak ikut dalam politik praktis, karena gereja bukanlah lembaga politik. ${ }^{43}$

Definisi yang dimaksud terlibat politik praktis adalah menunjukkan keberpihakan dan dukungan secara terang-terangan kepada calon pejabat negara maupun pejabat yang sedang memerintah. Politik praktis juga aktif untuk urusan-urusan partai politik. Itulah sebabnya, sebagian organisasi gereja-gereja tidak mengijinkan pendeta sekaligus juga menjadi anggota partai politik. Mengapa, karena ranah agama dan politik cenderung tidak bisa berjalan secara bersamaan. Agama selalu mendorong untuk tidak kompromi pada kesalahan, sementara politik cenderung mendorong seseorang kompromi pada kesalahan yang mengarah pada nepotisme. Haryatmoko menyatakan politik lebih banyak dipakai untuk memanipulasi kepentingan rakyat demi pencapaian kepentingan pribadi para pemimpin dengan alasan untuk kesejahteraan negara, nyatanya hanya kepentingan golongan. ${ }^{44}$ Mengaitkan agama ke dalam tindakan politik bergantung pada serangkaian kondisi yang melibatkan interaksi motif, cara, dan kesempatan. Bila keterlibatan agama dan politik merupakan kewajaran atau,tidak bermasalah. Namun perlu diperhatikan agama harus mampu menelaah dan mempertimbangkan tindakan politik itu tidak bertentangan dengan prinsip kebenaran agama itu sendiri. ${ }^{45}$

Memahami dinamika politik itu perlu sebagai seorang pemimpin organisasi gereja, namun terlibat ke dalam unsur politik praktis itu perlu dihindari. Organisasi gereja tidak akan dapat ditata dengan teratur bila pemimpin menceburkan diri dalam politik praktis. Karena tidak semua anggota yang dipimpin itu akan menyetujui pemimpinnya melibatkan diri dalam pusaran politik praktis. Susanta menyatakan politik praktis yang berlangsung kerap kali diwarnai sejumlah intrik yang menghalalkan segala macam cara demi mencapai tujuan termasuk dengan menyampaikan kabar bohong (hoaks) yang berpotensi memecah belah persatuan dan kesatuan. ${ }^{46}$ Pemimpin gereja yang nekat melibatkan diri dalam politik praktis, itu mengindikasikan bahwa ia tidak sepenuhnya memahami semua orang yang dipimpin. Jika pemimpin tidak memahami kondisi pengikut, maka untuk menggerakkan kearah tujuan organisasi mustahil akan tercapai. Oleh karena itu pemimpin sebagai penentu arah, dapat diibaratkan bagaikan alat (kompas) penentu arah yang digunakan oleh seorang nahkoda ditengah laut ke mana tujuan dan sasaran yang dituju. Tujuan suatu organisasi tentunya mengacu pada visi organisasi, tanpa visi maka organisasi tersebut bisa salah arah. ${ }^{47}$

Allah merancang organisasi gereja berdiri tujuannya bukan untuk berkolaborasi dengan politik. Organisasi gereja dirancang oleh Allah sebagai lembaga yang menata moralitas, memperbaiki perilaku orang percaya berdasarkan prinsip kebenaran firman Tuhan. Organisasi gereja hadir untuk mengkampanyekan prinsip-prinsip dalam menjalani

\footnotetext{
${ }^{43}$ Natonis, "Pemimpin Yang Menghamba, Bukan Diperhamba."

${ }^{44}$ Haryatmoko, Etika Politik Dan Kekerasan (Jakarta: Buku Kompas, 2003).

${ }^{45}$ Kenneth D Wald, Adam L Silverman, and Kevin S Fridy, "Making Sense of Religion in Political Life," Annu. Rev. Polit. Sci. 8 (2005): 121-143.

46 Yohanes Krismantyo Susanta, "Orang Kristen Dan Politik: Belajar Dari Kasus Salomo Dan Adonia Dalam Persaingan Menuju Takhta," DUNAMIS: Jurnal Teologi dan Pendidikan Kristiani (2019).

47 Daswati Daswati, "Implementasi Peran Kepemimpinan Dengan Gaya Kepemimpinan Menuju Kesuksesan Organisasi,” Academica 4, no. 1 (2012): 794.
} 
hidup jujur, amanah serta tidak kompromi kepada kebatilan. Sementara ranah politik, sarat dengan kompromi untuk berbuat kesalahan dan politik juga mengedepankan kepentingan pribadi. Tampenawas mengemukakan dalam Eklesiologi Calvin gereja dan negara merupakan dua hal yang diijinkan Tuhan untuk hadir dalam kehidupan di dunia, akan tetapi baik gereja maupun negara (politik) keduanya memiliki tugas dan tanggung jawab yang berbeda walaupun juga saling menolong satu dengan yang lain, ini juga menandakan tidak ada supremasi antara keduanya. Namun yang menjadi persoalan ketika politik bercampur aduk dengan pelayanan di dalam gereja, gereja menjadi kendaraan bagi politik. Inilah yang dinamakan dengan kegiatan politik praktis, dimana kepentingan pribadi maupun kelompok partai politik menjadikan gereja sebagai alat untuk mencari dukungan. ${ }^{48}$ Belajarlah kepada Yesus, ia memahami dinamika perpolitikan di masa itu, namun ia tidak pernah melibatkan diri dalam politik orang Romawi maupun Yahudi. Belajar pada kepemimpinan Yesus sebagai gembala dapat menolong para pemimpin masa kini untuk beradaptasi dengan lingkungannya. Yesus berdasarkan kasih-Nya dan karakter sebagai hamba memiliki kompetensi dan kecerdasan sosial yang tinggi, hadir dan bergaul di seluruh line stratifikasi sosial tanpa membeda-bedakan mereka. ${ }^{49}$

\section{Kesimpulan}

Organisasi gereja merupakan wadah atau sarana yang bertujuan mengatur dan menciptakan struktur kepengurusan jabatan yang jelas dalam gereja. Berdirinya organisasi gereja tentu atas seizin Tuhan yang diprakarsai oleh para hamba-Nya secara bersama-sama. Kehadiran organisasi gereja tentu untuk mengkoordinir kepentingan secara bersama-sama yang tergabung didalamnya. Dengan adanya organisasi gereja, struktur kepengurusan siapa yang menjadi pemimpin dan siapa yang dipimpin tergambar secara jelas. Acap kali kita dengar dan lihat, ada pemimpin-pemimpin organisasi gereja dalam menata organisasi tidak sesuai ekspektasi yang diharapkan oleh anggotanya. Akibatnya, antara pemimpin dan anggota timbul perdebatan, perselisihan, bahkan dapat berujung pada perpecahan ditubuh struktur organisasi. Oleh sebab itu, dalam memimpin organisasi gereja dibutuhkan model kepemimpinan yang ideal dalam penataan organisasi gereja. Adapun model kepemimpinan dalam penataan organisasi gereja yang perlu diperhatikan oleh seorang pemimpin adalah tidak sukuisme, terbuka kepada masukan dan kritikan, tidak mementingkan kepentingan pribadi maupun golongan serta tidak melibatkan diri pada pusaran politik praktis.

\section{Daftar Pustaka}

apriani, Fajar. "Menciptakan Pemimpin Yang Melayani." JAKPP (Jurnal Analisis Kebijakan \& Pelayanan Publik) 1, no. 1 (2015).

Asep Solikin, H.M Fatchurahman, Supardi. "Pemimpin Yang Melayani Dalam Membangun

48 Alfons Renaldo Tampenawas, "Pandangan Eklesiologi Calvin Mengenai Politik Praktis Dalam Pelayanan Gereja," THRONOS: Jurnal Teologi Kristen 1, no. 2 (2020): 115-126, http://ejournal.bmptkki.org/index.php/thronos/index.

${ }^{49}$ Ibelala Gea, "Kepemimpinan Yesus Teladan Pemimpin Masa Kini," Voice of Wesley: Jurnal Ilmiah Musik Dan Agama 3, no. 2 (2020): 35. 
Bangsa Yang Mandiri." Anterior Jurnal 16, no. 2 (2016).

Asnawati. "Pandangan Pemimpin Gereja Tentang Pengaturan Organisasi Gereja Di Provinsi Papua." Jurnal Multikultural \& Multireligius 14, no. 3 (2015).

Bentley, Wessel. "The Formation of Christian Leaders: A Wesleyan Approach." Koers 75, no. 3 (2010): 551-565.

Borrong, Robert P. "Kepemimpinan Dalam Gereja Sebagai Pelayanan.” Voice of Wesley: Jurnal Ilmiah Musik dan Agama 2, no. 2 (2019).

Clarke, Andrew David. “ Be Imitators of Me': Paul's Model of Leadership.” Tyndale Bulletin (1998).

Daswati, Daswati. "Implementasi Peran Kepemimpinan Dengan Gaya Kepemimpinan Menuju Kesuksesan Organisasi." Academica 4, no. 1 (2012).

Dedy Mulyana. No Metode Penelitian. Bandung: Rosdakarya, 2002.

Dody Hermana \& Ujang Cepi Barlian. "Komunikasi Dalam Organisasi." Jurnal Administrasi Pendidikan 2, no. 2 (2004).

Emzir. Metode Penelitian Kualitatif Analisis Data. Jakarta: PT Raja Frafindo Persada, 2016. Gea, Ibelala. "Kepemimpinan Yesus Teladan Pemimpin Masa Kini." Voice of Wesley: Jurnal Ilmiah Musik dan Agama 3, no. 2 (2020): 29-40.

Gregory, Tim. "Christian Leaders as Agents of Change: A Biblical Perspective with Practical Implications." In Modern Metaphors of Christian Leadership, 21-40. Springer, 2020.

Haryatmoko. Etika Politik Dan Kekerasan. Jakarta: Buku Kompas, 2003.

Hasibuan. M. Organisasi Dan Motivasi Dasar Peningkatan Produktivitas. Jakarta: Bumi Aksara, 2003.

Henry C Thiessen. Teologi Sistimatika. Edited by Vernon D Doerksen. 8th ed. Malang: Gandum Mas, 2010.

Kun Maryati. Sosiologi. Solo: PT. Tiga Serangkai Pustaka Mandiri, 2014.

Lang, Michael Kpughe. "The Patterns of Corruption in Christian Churches of Cameroon:

The Case of the Presbyterian Church in Cameroon." Transformation 31, no. 2 (2014): 132-144.

Michael J. Anthony. Foundaion Of Mnistry An Introduction Christian Education For A New Generation. Edited by Christian A Tomatala. Malang: Gandum Mas, 2012.

Natonis, Harun Y. "Pemimpin Yang Menghamba, Bukan Diperhamba." Voice of Wesley: Jurnal Ilmiah Musik dan Agama 2, no. 1 (2018).

Pramudyo, Anung. "Implementasi Manajemen Kepemimpinan Dalam Pencapaian Tujuan Organisasi." Jurnal bisnis, manajemen, dan akuntansi 1, no. 2 (2013).

Raharjo, Susilo Toto, and Durrotun Nafisah. "Analisis Pengaruh Gaya Kepemimpinan Terhadap Kepuasan Kerja, Komitmen Organisasi Dan Kinerja Karyawan (Studi Empiris Pada Departemen Agama Kabupaten Kendal Dan Departemen Agama Kota Semarang)." Jurnal Studi Manajemen Organisasi 3, no. 2 (2006): 69-81.

Reslawaty. "Pandangan Pimpinan Gereja Tentang Pengaturan Organisasi Gereja Di Provinsi Jawa Barat." Jurnal Multikultural \& Multireligius 13, no. 3 (2014).

Santoso, C Budi. "Exploration Of Asia Leadership Theory: Looking For An Asian Role In 
The Field Of Leadership Theory." Journal of Leadership in Organizations 1, no. 1 (2019).

Sari, Herlinda Maya Kumala. "Pengaruh Budaya Organisasi Dan Gaya Kepemimpinan Otoriter Terhadap Loyalitas Melalui Kepuasan Kerja Dan Stres Kerja Karyawan Institusi X Di Kediri.” JBMP (Jurnal Bisnis, Manajemen dan Perbankan) 2, no. 1 (2016): 15-30.

Sitepu, Elisabeth. “Kepemimpinan Kristen Di Dalam Gereja.” Jurnal Pendidikan Religius 1, no. 1 (2019): 7-11.

Suhadi, Suhadi, and Yonatan Alex Arifianto. "Pemimpin Kristen Sebagai Agen Perubahan Di Era Milenial." EDULEAD: Journal of Christian Education and Leadership 1, no. 2 (2020): 129-147.

Suherman, Usep Deden. "Pentingnya Kepemimpinan Dalam Organisasi." Jurnal Ilmu Akuntansi Dan Bisnis Syariah 1, no. 2 (2019).

Suryana. "Pentingnya Kecerdasan Emosi Bagi Kepemimpinan Yang Efektif Di Era Milenial Revolusi 4.0." Jurnal Inspirasi 10, no. 1 (2019).

Suryana, Asep. "Membangun Kepemimpinan Yang Menyenangkan." PEDAGOGIA 12, no. 1 (2014): 32-39.

Susanta, Yohanes Krismantyo. "Orang Kristen Dan Politik: Belajar Dari Kasus Salomo Dan Adonia Dalam Persaingan Menuju Takhta." DUNAMIS: Jurnal Teologi dan Pendidikan Kristiani (2019).

Tampenawas, Alfons Renaldo. "Pandangan Eklesiologi Calvin Mengenai Politik Praktis Dalam Pelayanan Gereja.” THRONOS: Jurnal Teologi Kristen 1, no. 2 (2020): 115126. http://e-journal.bmptkki.org/index.php/thronos/index.

Tanyid, Maidiantius. "Kualitas Pemimpin Sebagai Pendidik Dalam Menghadapi Konflik." BIA': Jurnal Teologi dan Pendidikan Kristen Kontekstual 1, no. 1 (2018): 124-137.

Team Balai Pustaka. Kamus Besar Bahasa Indonesia. 3rd ed. Jakarta: Balai Pustaka Departemen Pendidikan Nasional, 2003.

Usman, Husaini. "Kepemimpinan Berkarakter Sebagai Model Pendidikan Karakter.” Jurnal Pendidikan Karakter 3, no. 3 (2013).

Wald, Kenneth D, Adam L Silverman, and Kevin S Fridy. "Making Sense of Religion in Political Life." Annu. Rev. Polit. Sci. 8 (2005): 121-143.

Watt, Willis M. "Relational Principles for Effective Church Leadership." Journal of Leadership Education 13, no. 2 (2014): 125-139.

Welton, Anjalé D, Devean R Owens, and Eboni M Zamani-Gallaher. "Anti-Racist Change: A Conceptual Framework for Educational Institutions to Take Systemic Action." Teachers College Record 120, no. 14 (2018): 1-22.

Widjaja, Raymondus Indra. "Implementasi Karakter Pemimpin Kristen." Agora 3, no. 1 (2015): 672-676.

Wijaya, Yahya. "Kepemimpinan Yesus Sebagai Acuan Bagi Kepemimpinan Gereja Masa Kini." Jurnal Jaffray 16, no. 2 (2018): 129-144.

"Tuhan Pun Diminta Untuk Memenangkan Prabowo.... - Kompasiana.Com." 